\title{
Rationality and Belief in Middle Ages
}

\author{
Zouyi Huang \\ School of Marxism \\ Wuhan University of Science and Technology \\ Wuhan, China
}

\begin{abstract}
The relationship of rationality and belief, which is the core issue of the Middle Ages, throughout the whole progress of medieval philosophy's formation, prosperity and fading. The Middle Ages of European is known for corruption and cruel carnage of policy, various taxes and unbridled plunder as well as brainwash and ignorant rule, in which cases, it is deemed as the "Age of Darkness". The rule of fideism makes rational thoughts become people's exclusion zone and people's nationality become servant of the fideism. Due to absolute monopoly of single religion, it is inevitable to make theory related to religion simply become tools for demonstrating special religious creeds as well as theology serving fideism. Nevertheless, there is no lack of philosophic wisdom shining during the time and tide of over one thousand year long so that it is worthy for us to pay attention or research on the argument of rationality and belief.
\end{abstract}

Keywords—nationality; belief; scholasticism; thomas

\section{INTRODUCTION}

In fact, provided that one equal and objective appraisal should be given this age by dialectic attitude, medieval philosophy continues with the development track in an unique form, inherits the nationality tradition of western philosophy and develops in the communication between rational scientific spirit and the religious spirit of belief.

\section{RATIONALITY OF RELIGIOUS BELIEF}

\section{A. God: The Root of Human Nationality}

Upon god is created by people and clearly known who it is, which means people attempts to approach belief in rational ways instead of dividing them. In Christian world, the nationality and belief are never independent, not mentioning standoff or conflict said by some scholars. While this dualistic relationship is absolutely unified herein and an indecomposable thought model. The conception of God is to expound the meaning of human beings actually; the enlightenment of God is to restrain human beings' behaviors; and the desire of human beings for belief is to pursue nationality.

\section{B. Human Beings: Reappearance of God's Will}

No question in the world is older than the question human beings asking to themselves: Who am I? In Christian culture, people create the image of God based on theirs that god's will represents theirs, with spirit same to god. This kind of understanding on human beings in Christian culture is also the

*Zouyi Huang, Master candidate of Wuhan University of Science and Technology. greatest confirmation to human beings per se so far.

Due to human in spirit made by God, one important thing is given to human beings as a gift as well: free will.

Hence, the "human" in Christian culture is more stressed a kind of spirit characteristics, which born of God or the existed form of God. From this human with God characteristics form, we can see the confirmation of the strength and value on human beings. So that, people believe God is to pursue themselves and affirm themselves. This is the integration of rationality and relief expressed in the definition of "human" in Christian culture. [1]

\section{EARlY ChristiAn THEOLOGY}

In order to strive for and strengthen its victory, widen its influence and oppose attacks from various aspects (religion, philosophy and politics), Christianity has established a series of theological theories for defending the creed and proving the doctrine. Of course, whereby, it also has debased and denied the pagan to establish Christianity's supremacy in the religion world. At this point, although it has devout beliefs, it hasn't systematic theological theories. But Greek philosophy has mature rationality critical ability, so being forced by the need of spreading and development, Christianity had to use philosophy. Therefore, the early Christianity has belittled rationality on one hand, but on the other hand, it has selectively accepted Greek Philosophy. With the help of Philosophy's reflection, it has gradually become rational, which makes the Christian theology be rapidly theorized and systemized.

The rationality of this period would exist by relying on belief. Take Augustinus - the master of patristic philosophy in Middle Ages as an example. His well-known saying is that I believe it because it is absurd. He propositions are that: belief is higher than rationality, rely on mystical intuition to know God, but God can be perceived and can use metaphysical reasoning method to prove. Therefore, rationality should be introduced to theology to some extent and rationality and belief should be combined. With people's increasing pursuit for rationality, doubts about doctrines are more and more. The early Fathers also gradually have realized the blindness of belief without rationality. In order to make Christian belief become a universal phenomenal, it has to withstand the test of rationality and get rationality's approval. And the belief with rationality is the most reliable. However, rationality does not go beyond the limits of belief. "Patristic philosophy always gives its trust to rationality within the limit of belief. Even 
Augustinus is there, this limit would never been relaxed to the point where one can ask whether God exists or why God exsits."

Christianity has done theoretical reflections over its doctrines and used the unification of theories to promote that of practice. But this kind of reflection can only use the philosophical way. With the help of philosophical reflection, Christianity has achieved self-consciousness, and Christian belief has gradually walked on the road of rationality. At least it makes Christian belief get rid of some blind obedience and fanaticism for authority

The Christian theology here has mainly addressed three problems: the first is Holy Trinity namely God's unity problem; the second is the jealous divinity and humanity problem, which is the unity of Christ; the third is human beings' original sin and salvation way, which is the relationship problem between God and human beings.

From the perspective of modern science, these problems are useless, niggling, absurd and ridiculous. The problems themselves they discussed are fictional existence. No matter how Fathers imaged these problems, they are just holy nonsense. Holy Trinity, christology and salvation in any form cannot help for people knowing the essence of religion, or lead people to step toward the religion of science.

However, it is undeniable that these have great significance for rational religion research.

- Early Fathers have discussed these problems with a serious and earnest attitude. They have not only promoted these abstract theological problems according to the actual needs of religion conflicts, but applied ancient Greek philosophy to speculatively discuss them. This has made Christian theology go beyond the general level of men and women blindly believing, but have the color of theoretical thinking, which has deepened the religion research and promoted the religious theoretical thinking;

- Holy Trinity, christology and salvation in early Christianity has practically laid foundation for western Christian theology, which has a deep and lasting influence over the whole western thinking and culture. In a long historical period, various philosophical and religious doctrines, no matter doctrines of religion guardianship or Enlightenment thought and atheism of religion opposing, cannot surpass them and have to issue their own answers. This has constituted an opportunity to promote the development of philosophy and religion.

Certainly, the rational factors in early Fathers' theology are very limited. The most basic fact is that: these so-called statements are essentially anti rational. The fancy philosophical arguments done by Fathers are just ambiguous concept games. To have people believe this holy nonsense, they have to use the compulsion of belief. Once in the key occasions, they would take off the rational coat which overcoats theology, and begin to preach a naked belief and obscurantism.
"The First Latin Fathers " - Tertullianus has indicated that: the son of God is dead, which is not reasonable but believable. The buried son of God is relived, which is impossible but affirmable. In a word, belief is absolute reliable and church has absolute authority. [3]

"Philosophical Charlemagne the Great in Middle Ages" Erigena has taken the unification of rationality and belief as the guiding principle of philosophical epistemology. He believes that revelation and rationality both are the resource of truth, religion and philosophy have the same authority, and use rationality when there is contradictions between belief and rationality. This is in fact to affirm rationality being above belief. In On the Distinction between Nature, he writes, "authority is derived from the true rationality, but rationality is not derived from authority. Because the authority that does not proved by true rationality is weak. On the contrary, because it is reliable, forever and based on its own authority, the true rationality does not need to compromise to a certain authority for proving itself." This thought that praises rationality and denounces to blindly believe forms a sharp opposition with Tertullianus.

\section{SCHOLASTICISM}

If patristic philosophy is the unification of theology and philosophy, namely rationality is lower than belief and exists by attaching to belief, the emerging of scholasticism has had some fundamental progress comparing with the past Augustinus theology namely patristic philosophy. Philosophy has separated itself from theology little by little, and been gradually independent from theology.

No-belief and no-rationality cannot be called medieval philosophy. In essence, the medieval philosophy has served for belief but been an activity of rationality. Starting from the interest of Science, it has encouraged and praised the free research spirit. It has turned the object of belief to that of thinking, led man from the field of absolute belief to that of doubting, researching and knowing. Striving for demonstrating the object of belief based upon authority, it thus has proved that, although the most having violated its understanding and will namely the authority of rationality, has introduced a principle different from the principle of the old church -- spirit of independent thinking, rational self consciousness, or at least preparing for this principle. Therefore, the basic spirits of scholasticism in Middle Ages are not blind belief which totally rejects rationality, but are the typical of the intermediation and reconciliation of rationality and belief.

Thomas has combined Aristotle's philosophy and Christian theology, making a new form for Christianity's theology. He thinks that the truth of God's revelation directly comes from God's inspiration. Although it cannot be proved by rationality or philosophy, it is not the objection of rationality, but is beyond human beings' rationality. If people just believe things which are proved by rationality or philosophy, actually, belief will be undermined. Thomas has waved the banner of natural reason on one hand, and attempted to use philosophical inference to prove the reasonability of Christianity's beliefs; on the other hand, he has affirmed God's revelation that philosophy and rationality can never reached. 
When emphasizing philosophy and other knowledge are the servants of theology, Thomas has strongly stressed that philosophy and other knowledge should serve for theology, and running parallel, the two kinds of knowledge are two different aspects of the same truth's progress. Belief can broad horizon for rationality and supplement rationality's deficiencies, so that perfect philosophy's truth; while rationality and philosophy can provide proof for belief and theology, so that affirm theology's truth. He has used the two sides of coin to figuratively express the relationship between rationality and belief.

In the front of Thomas's religious theology, the philosophy based on natural rationality and other knowledge has had a humble status. However, Thomas has waved the banner of rationality and philosophy, and tried to give philosophical proof to religious doctrines. In his works, the philosophical reasoning mode has been widely used; he has deeply understanding about Aristotle's philosophical principles and categories, which has practically improved the value and status of rationality and philosophy. As for objective effect, it is no doubt that rational discussion and philosophical thinking about religious problems of later scholars will be stimulated, which obviously has contributed to religious research walking on the rational road. Especially, because rationalism and fideism, philosophy and theology are essentially opposed to each other, stressing to use rationality and philosophy to prove theology makes religious theology undergo a rational and philosophical examination sooner or later and accept tests unacceptable for it.

Beliefs in Middle Ages always exist with the tension of rationality. The internal division of scholasticism in 14th century is mainly manifested in the debate of Thomasism, Scottism, Ockhamism and other doctrines. The focus of debate is a contest between different rationalities rather than the conflict between rationality and belief. These rationalities have come from Greek philosophy, but differences between them have resulted in their differing understandings about belief and doctrine, so that conflict has been produce. Although each school has accused others of deviating from belief, in essence, these debates are not conflict between rationality and belief. Until 16th century, leaders of religion reform have explained the doctrine of Holy Bible in a de-Greek way, and opposed the Greek rational spirits in scholasticism, which has led to the fundamental conflict between belief and rationality. Thereafter, the Greek rationality which had combined with belief has to yield to the new rationality which had allied with modern science, and the scholasticism has to yield to modern philosophy. [4]

The premise of the above summary is that: firstly, medieval rationality is the inheritance and promotion of the rational spirits of Greek philosophy; secondly, rationality and belief in Middle Ages have contradictions and harmonies; lastly, harmony is the product of contradiction.

\section{DECLINE OF SCHOLASTICISM'S ORTHODOX THEOLOGY}

Represented by Thomas Aquinas, the scholastic theology has used logical reasoning to demonstrate religious beliefs under the banner of rationality. Although a glorious chapter in
Theology has been written, contradiction between belief and rationality haven't been addressed. There are two aspects of hidden dangers inside the Christianity: one is the supporters that make Christian doctrine be established on divorcing from belief; the other is a school that wishes rationality to break the fetters of belief and walk in its own way toward the philosophy and theological doctrine having a sense of Enlightenment.

John Duns Scotus has thought that there is no conflict between the truth of belief and that of rationality. Just think that rationality has limits and cannot illustrate the mystery of religion. The basis of religious theology is not rationality or philosophy but is belief in that only belief can make the mystical doctrines reliable. However, belief is a matter of the will, having nothing to do with rationality or knowledge. On the other hand, philosophy, having its own independent principles, is an independent science that does not belong to theology.

In his thoughts, the compliance relationship between philosophy and theology has been cut off, which possibly results in certain ideological emancipation.

William of Occam has clearly distinguished knowledge and belief, philosophy and theology. He thinks that the power of the church is limited to the religious world, and the basis of theology is revelation and belief, having no right to interfere in the field of knowledge. Rational argument on belief has become a false proposition. However, God is not the object of knowledge, so no matter sense or reason cannot provide a truthful definition about God. And God's property and function (including infinite and other function) cannot be proved. Human beings should give up this kind of judge. The above two persons with irrational theology are representative figures in opposing the rational theology of Thomas, and also are supporters of relativism and skepticism. They have intended to strictly limit religion' theology in the field of belief and to liberate philosophy and rationality.

\section{SigNifiCANCE OF THE DEBATE BETWEEN RATIONALITY AND BELIEF IN MIDDLE AGES OF EUROPE}

From the relationship between reason and belief, the developing process of European ancient philosophy can be generalized as follows: the first is a spontaneous affirmation of the rational function in ancient Greek-Roman period; second is the dominant position of medieval theological belief; then, come into the new consciousness of the Renaissance and modern rationality. Happening to be the intermediary in this process, Middle Ages naturally has great significance.

On one hand, the debate between rationality and belief of medieval philosophy has promoted the rational tradition of ancient Greece and Rome.

- The debate itself has denied the absolute authority of belief, and made the occurrence of the transition from blind belief to rational belief.

- The debate has reproduced the spirit of doubt. Doubt about the doctrine of Holy Bible in the age of Augustinus, doubt about the doctrine of "entity transformation" of Lateramnus, a monk in Kolbe 
monastery, France, and doubt spirit strongly advocated by Abelard in his Right and Wrong all have reappeared the gleaming of rationality in ancient Greek-Roman philosophy. Doubting about belief is a sign of rational progress.

- The debate between rationality and belief has promoted people's exploration of nature and Science. It is manifested in the presenting of various natural and social problems, and meanwhile in the establishment of missionary schools and famous universities in Europe. It is exactly in the contradiction between rationality and belief that ancient universities in Europe such as University of Oxford, University of Paris, University of Cambridge, University of Toulouse and University of Naples Federico have been established one after another. These universities which have objectively promoted the development of rationality, are the research center of scholasticism, and naturally are the center of ideological culture and scientific research.

- The debate between rationality and belief of medieval philosophy has laid foundation for the overall revival of rationality in Renaissance.

Debate between rationality and belief in Middle Ages has actually continued the transition from the philosophical study of the external world to that of human's own problems. On one hand, it has confirmed further and theologically the relationship between man, the subject and God, the object. While on the other hand, it has deepened human's understanding of their own rational ability. In this debating process of the relationship between rationality and belief, people have strengthened their research on rationality and self recognition ability.

As a major achievement in medieval philosophy, human beings' deepening understanding about rationality itself has combined with the development of Natural Science in late Middle Ages, leading to confirm human beings' subjectivity. At last, it has developed into the full revival of human's rationality which takes overthrowing the church theology as a sign. During Renaissance, philosophers has raised the banner of Humanism which uses "humanitarian" against "shinto", advocates "individual liberation" and "individual happiness" and affirms "human dignity". Think that human beings can fully exert their wisdom, knowledge and strength to reveal all secrets of nature. This is exactly the extension and transcendence of advocating rationality and opposing blind belief of philosophical forerunners in the debate between medieval rationality and belief.

\section{REFERENCES}

[1] Li Min, Thinking on Relationship between Rationality and Belief in Medieval Philosophy [J]. Philosophical Research

[2] Li Xiangyun, Christian culture: the unity of Rationality and Belief[J] Longyan Teachers Training School, 2003.8: 25

[3] Liu Bo. A Brief Analysis of the Debate between Rationality and Belief in the Middle Ages of Europe [J]. Journal of Guizhou Normal Univrsity (Social Science), 2000,7:61-62
[4] Zhao Dunhua. Some Key Issues in the Research on Mediaeval Philosophy - after reading Rationality and Belief: Western Medieval Philosophy $[\mathrm{J}]$. Journal of Peking University (Philosophy and Social Science), 2007,44(1):49-50 